The Catholic University of America, Columbus School of Law

CUA Law Scholarship Repository

\title{
Lafler and Frye: Good News for Public Defense Litigation
}

Cara H. Drinan

The Catholic University of America, Columbus School of Law

Follow this and additional works at: https://scholarship.law.edu/scholar

Part of the Criminal Procedure Commons

\section{Recommended Citation}

Cara H. Drinan, Lafler and Frye: Good News for Public Defense Litigation, 25 FED. SENT'G REP. 138 (2012).

This Article is brought to you for free and open access by the Faculty Scholarship at CUA Law Scholarship Repository. It has been accepted for inclusion in Scholarly Articles by an authorized administrator of CUA Law Scholarship Repository. For more information, please contact edinger@law.edu. 


\section{Lafler and Frye: Good News for Public Defense Litigation}

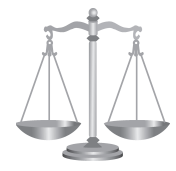

CARA H. DRINAN*

Associate Professor of Law, Columbus School of Law, The Catholic University of America
This past term, in Missouri v. Frye ${ }^{\mathrm{I}}$ and Lafler v. Cooper ${ }^{2}$, the Supreme Court confirmed that the Sixth Amendment right to counsel applies to the plea negotiation process and held that prejudicial error can flow from ineffective plea advice. The defense community has applauded these decisions for recognizing the pivotal role that guilty pleas play in our criminal justice system and for requiring a minimum level of efficacy in plea lawyering. Although some have expressed concern about the implementation of the two decisions, ${ }^{3}$ others argue they will lead to better plea policies within prosecutors' offices and closer judicial supervision of plea deals. ${ }^{4}$ In this brief essay I want to suggest that Frye and Lafler are victories for the defense community in yet another way. The decisions reflect judicial realism, and in this respect, they are especially important cases for systemic public defense litigation.

Both opinions, authored by Justice Kennedy, are firmly rooted in the realities of today's criminal justice system. The Frye decision held that counsel's failure to notify a client of a favorable plea offer constitutes ineffective assistance, ${ }^{5}$ and in Lafler the Court found that counsel's mistaken view of the law, which induced the defendant to reject a plea and go to trial, was equally ineffective. ${ }^{6}$ If the four dissenting Justices had had their way, the cases would have been dismissed on the grounds that (I) there is no constitutional right to a plea offer, ${ }^{7}$ and (2) in any event, the subsequent trial in Lafler's case and the plea agreement in Frye's case "wipe[d] clean any deficient performance by defense counsel during plea bargaining." 8 Yet the majority in both cases rejected the claim that the Sixth Amendment protects only the right to a fair trial. ${ }^{9}$

The Frye decision noted that $97 \%$ of federal convictions and $94 \%$ of state convictions are secured through guilty pleas. ${ }^{\text {IO }}$ In light of that fact, the Frye Court held that, in most cases, the plea bargaining process is "the critical point for a defendant," "II and thus "it is insufficient simply to point to the guarantee of a fair trial as a backstop that inoculates any errors in the pre-trial process." ${ }^{\text {"2 }}$ By recognizing that the plea negotiation process is not simply an "adjunct to the criminal justice system," "13 but, in fact, its defining feature, the Court embraced realism in its Sixth Amendment case law.

Because the Lafler and Frye decisions reflect such pragmatism, they may prove to be powerful precedent for defense reform advocates who seek relief in court. Too often, courts dealing with public defense reform litigation decide cases in a formalistic way that prevents the underlying constitutional issues from being addressed. For example, federal courts historically have refused to hear systemic public defense suits on abstention grounds. ${ }^{\text {I4 }}$ At the same time, state courts have viewed public defense reform as a legislative prerogative, directing plaintiffs to the political process. ${ }^{15}$

In recent years, there have been some notable successes in defense reform litigation, ${ }^{16}$ but plaintiffs who claim that an entire public defense system is broken regularly face the same two formalistic arguments from lawyers for the defendant states: first, that legislatures, not courts, are best suited to generate indigent defense reform, and second, that plaintiffs should pursue their claims in postconviction proceedings. Courts that accept this former argument ignore two realities: (I) legislatures are unlikely to take up indigent defense reform because there is no lobby for such an effort, and (2) courts do have a role to play in defining constitutional rights, even when those definitions implicitly call upon legislators to allocate funding. ${ }^{17}$ Courts that accept the second argument- that postconviction is the most appropriate avenue for relief-also ignore reality. Specifically, these courts overlook three practical facts: (I) postconviction relief is retrospective and thus inappropriate when a party seeks prospective, systemic reform ${ }^{\mathrm{I} 8} ;(2)$ individual defendants rarely prevail in an ineffective assistance claim because the legal standard insulates even the most egregious cases of inefficacy ${ }^{19}$; and (3) individual habeas relief in state or federal court does not allow a defendant to demonstrate features of an entire system that may have contributed to, if not caused, ineffective lawyering in one particular case. When courts dismiss public defense reform suits, arguing that these suits present insurmountable separation of powers concerns or that an alternative remedy is available-even though in name only-these courts value formalism over the practical realities that face criminal defendants today.

The Lafler-Frye decisions offer a counterpoint to that kind of formalism, and counsel in current public defense suits should leverage these decisions accordingly. Two current defense reform suits deserve mention, one recently decided in Missouri and one ongoing in Florida. In Missouri, the indigent defense function has been struggling for years because of insufficient funding and excessive caseloads. ${ }^{20}$ In 2007, the Missouri Public Defender Commission adopted a protocol for determining the maximum number of cases that each of its offices could effectively handle. ${ }^{2 \mathrm{I}}$ In 20IO, having attempted to implement this protocol and its workload limits, the state public defender

Federal Sentencing Reporter, Vol. 25, No. 2, pp. I38-I40, ISSN 1053-9867, electronic ISSN 1533-8363. (C) 2012 Vera Institute of Justice. All rights reserved. Please direct requests for permission to photocopy or reproduce article content through the University of California Press's Rights and Permissions website, http://www.ucpressjournals.com/reprintInfo.asp. DOI: I0.I525/fsr.20I2.25.2.I38. 
filed a motion to set aside the appointment of new cases until workloads dropped to a point at which defense attorneys could handle new cases. ${ }^{22}$

The trial court judge overruled the motion and held he had no choice but to appoint the public defender-effectively thwarting the defender office's workload protocol altogether. ${ }^{23}$ On appeal, the Missouri Supreme Court considered whether the public defender, under its current regulations, could refuse new cases when its workload prevents effective representation of additional clients. ${ }^{24}$ In a 4-3 decision, the state Supreme Court held that the public defender acted pursuant to valid regulatory authority in devising its workload protocol, and thus its refusal of additional cases was lawful. Moreover, the Court's opinion makes clear that the refusal of new cases was also appropriate in light of prevailing ethical standards and the Sixth Amendment requirement that indigent defendants have effective and "not just pro forma, representation." 25 In its ruling, the majority dealt with the realities of Missouri's indigent defense workload crisis, rejecting the argument of mootness that has plagued past defense reform suits.

The Miami-Dade County Public Defender's office in Florida can only hope for a similar outcome in its pending case. Florida statutory law currently bars courts from allowing a public defender to withdraw from a case because of an excessive workload. ${ }^{26}$ Since 2008 , not only has the public defender in Miami-Dade County been seeking withdrawal from cases because of workload concerns, but the office has also challenged the constitutionality of this statutory language. ${ }^{27}$ The public defender has argued that its attorneys have a professional and constitutional obligation to decline new cases when they have reached their workload capacity. The Florida Supreme Court heard oral arguments in this case in June, ${ }^{28}$ and it is not clear when a decision will be released.

The Missouri and Florida cases are not simply cases about whether the state legislature has the right to intrude upon the state court's own internal management or whether a public defender office has the statutory right to control its workloads using internally generated metrics. In both jurisdictions excessive caseloads are a glaring fact-by any measure. In Florida, one of the assistant public defenders whose caseload was at the heart of the lawsuit handled more than 700 felonies and more than 200 pleas at arraignment in fiscal year 2008-2009. ${ }^{29}$ In Missouri, a 2009 state Supreme Court opinion dealing with the issue of excessive caseloads documented that state defenders had the capacity to "spend only 7.7 hours per case, including trial, appellate and capital cases." 30 When attorneys are operating under such crushing workloads, they are not capable of providing anything close to effective representation. These obvious, practical realities should inform state courts considering public defense reform suits, just as actual facts about the practice of criminal law today informed the Lafler-Frye decisions.

It is unlikely the Supreme Court even considered public defense litigation when it rendered decisions in the
Lafler-Frye cases. Nonetheless, attorneys seeking public defense reform in court can now point to the realism of the Supreme Court in deciding Sixth Amendment cases. At least one such attorney has already done so. In his closing argument, Parker D. Thompson, counsel for the Miami-Dade County Public Defender, mentioned Lafler and Frye explicitly and discussed the reality of his client's workload. ${ }^{3 \mathrm{I}}$ According to the evidence on record, the public defender testified that in $40-50 \%$ of his cases, he had no opportunity to brief his clients before they entered a plea. As Mr. Thompson said in closing, "the public defender has to deal with reality." Courts presiding over public defense reform suits should do the same, and the Lafler-Frye decisions enable such a stance.

\section{Notes}

* I received valuable feedback from Andrew Ferguson, Amanda Leiter, and Megan La Belle.

1 Missouri v. Frye, 132 S. Ct. 1399 (2012).

2 Lafler v. Cooper, 132 S. Ct. 1376 (2012).

3 The dissenting Justices in the two cases have vocalized the sharpest criticisms to date. See e.g., Lafler, 132 S. Ct. at 1398 (Scalia, J., dissenting) ("Today's decision upends decades of our cases, violates a federal statute, and opens a whole new boutique of constitutional jurisprudence ('plea-bargaining law') without even specifying the remedies the boutique offers."); Id. at 1398-99 (Alito, J., dissenting); Frye, 132 S. Ct. at 1412-13 (Scalia, J., dissenting) (predicting difficulty lower courts will have in defining responsibilities of defense counsel in plea bar. gain process). Some academics have also recognized potential implementation concerns. For an example of the latter, see Gerard E. Lynch, Frye and Lafler: No Big Deal, 122 Yale L.J. Online 39, 41 (2012) (citing difficulties with applying the new rules but ultimately determining that courts can sufficiently handle them).

4 Norman L. Reimer, Frye and Lafler: Much Ado about What We Do-and What Prosecutors and Judges Should Not Do, Champion Magazine, April 2012, 7-8.

5 Frye, 132 S. Ct. at 1408.

6 Lafler, 132 S. Ct. at 1387-88.

7 Id. at 1395 ("As the Court itself observes, a criminal defendant has no right to a plea bargain.").

8 Id. at 1388.

9 Frye, 132 S. Ct. at 1405; Lafler, 132 S. Ct. at 1385-86.

10 Frye, 132 S. Ct. at 1407.

11 Id. (emphasis added).

12 Id.

13 Id. (quoting Robert E. Scott \& William J. Stuntz, Plea Bargaining as Contract, 101 Yale L.J. 1909, 1912 (1992)).

14 See e.g., Luckey v. Miller, 976 F.2d 673, 678 (11th Cir. 1992); see also Cara H. Drinan, The Third Generation of Indigent Defense Litigation, 33 N.Y.U. Rev. L. \& Social Change 427, 440-41, 468-74 (2009) (discussing the lack of a federal forum for these suits and making the case that federal courts err in abstaining from public defense reform suits).

15 See, e.g., Duncan v. State, 486 Mich. 1071 (2010) (summarily dismissing a class action suit by indigent defendants on grounds of nonjusticiability; order vacated on reconsideration by Duncan v. State, 488 Mich. 957 (2010)); State v. Bowens, 39 So.3d 479 (Fla. App. 3 Dist. 2010) (rejecting defender's claim that excessive caseload created a conflict of interest and stating that a funding issue cannot be basis for withdrawal); $c f$. Kennedy v. Carlson, 544 N.N.W.2d 1 (Minn. 1996) (dismissing defender office's claim that the statutory funding cap was unconstitutional for failure to state a claim). 
16 See, e.g., Hurrell-Harring v. State, 15 N.Y.3d 8 (N.Y. 2010) (holding that indigent defendants stated a claim for constructive denial of Sixth Amendment right to counsel.). In the Michigan public defense class action mentioned, supra note 15, the Michigan Supreme Court, after reversing itself twice, ultimately allowed the suit to move forward. See David Carroll, Gideon Alert: As Michigan Supreme Court Again Reinstates ACLU Duncan Lawsuit, the Race to the Bottom Continues in Chippewa and Bay Counties, Dec. 2 2010, available at http://www.nlada. net/jseri/blog/gideon-alert-michigan-supreme-court-againreinstates-aclu-duncan-lawsuit-race-bottom-cont.

17 Hurrell-Harring, 15 N.Y.3d at 26 ("It is, of course, possible that a remedy in this action would necessitate the appropriation of funds and perhaps, particularly in a time of scarcity, some reordering of legislative priorities. But this does not amount to an argument upon which a court might be relieved of its essential obligation to provide a remedy for violation of a fundamental constitutional right." (citation omitted)).

18 Luckey v. Harris, 860 F.2d 1012, 1017 (11th Cir. 1988) ("[The Strickland] standard is inappropriate for a civil suit seeking prospective relief. The Sixth Amendment protects rights that do not affect the outcome of a trial. Thus, deficiencies that do not meet the 'ineffectiveness' standard may nonetheless violate a defendant's rights under the Sixth Amendment. In the post-trial context, such errors may be deemed harmless because they did not affect the outcome of the trial. Whether an accused has been prejudiced by the denial of a right is an issue that relates to relief-whether the defendant is entitled to have his or her conviction overturned-rather than to the question of whether such a right exists and can be protected prospectively."); Hurrell-Harring, 15 N.Y.3d at 23-24 (finding that plaintiffs' claims were prospective in nature and distinct from a claim of ineffective assistance of counsel).

19 Nat'l Right to Counsel Comm., the Constitution Project, Justice Denied at 40-41 (2009) (describing near unanimous criticism of standard), available at http://www.constitutionproject.org/ pdf/139.pdf.

20 State ex rel. Missouri Public Defender Com'n v. Pratte, 298 S. W.3d 870, 875-78 (Mo. 2009) (discussing history of public defenders and its challenges).

21 Id. at 878.

22 State ex rel. Missouri Public Defender Com'n v. Waters, 8-9 (No. SC91150) (Jul. 31, 2012), available at http://www.courts. mo.gov/file.jsp?id=55767.

23 Id. at 9-10.

24 Id. at 17

25 Id. at 21

26 Fl. Stat. 27.5303(1)(d)(2007).

27 See Wayne A. Logan, Litigating the Ghost of Gideon in Florida: Separation of Powers as a Tool to Achieve Indigent Defense Reform, 75 Mo. L. Rev. 885, 891-97 (2010).

28 Public Defender, Eleventh Judicial Circuit v. State (SC09.1181, SC10-1349).

29 Logan, supra note 27, at 895.

30 Pratte, 298 S.W.3d at 873.

31 The oral arguments in the Miami-Dade litigation before the Florida Supreme Court are available at http://wfsu.org/ gavel2gavel/archives/flash/viewcase. php?case=09.1181_ 10.1349. 